
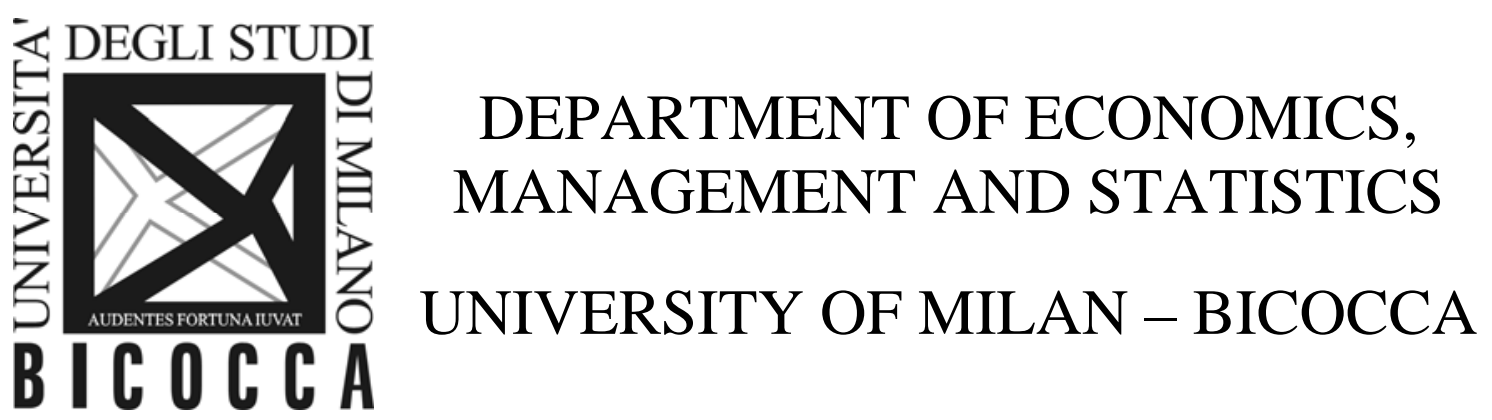

DEMS WORKING PAPER SERIES

\title{
Ethnic Minority Concentration: A Source of Productivity Growth for Italian Provinces?
}

Alessandra Michelangeli, Nicola Pontarollo

No. 349 - August 2016

Dipartimento di Economia, Metodi Quantitativi e Strategie di Impresa

Università degli Studi di Milano - Bicocca

http://dems.unimib.it/ 


\title{
Ethnic Minority Concentration: A Source of Productivity Growth for Italian Provinces? ${ }^{\S}$
}

\author{
Alessandra Michelangeli*, Nicola Pontarollo\$
}

July, 2016

\begin{abstract}
This paper aims at assessing the contribution of ethnic minorities to the productivity of the main sectors of Italian provinces. To this end, we consider the first ten nationalities by numbers of regularised persons observed at the provincial level (NUTS-3) between 2003 and 2011. We use an empirical panel growth model with spatially augmented specifications, which allows to capture both the direct (marginal) and indirect (spillover) effects of each community on local productivity at the provincial level. Our findings show that two communities out of ten have a positive impact on economic performance of Italian provinces. Other foreign groups have significant effects only indirectly, meaning that these groups do not affect growth of provinces where they live, but the neighbouring provinces likely because of commuting.
\end{abstract}

Key Words: productivity growth; specialisation; spatial econometrics; foreigners.

JEL Codes: R11; R12; R23.

\footnotetext{
$\S$ Financial support by the Italian Ministry of University and Research is gratefully acknowledged. The usual disclaimer applies.

*DEMS - University of Milan-Bicocca, Piazza dell'Ateneo Nuovo 1, 20126 Milan (Italy). E-mail address: alessandra.michelangeli@unimib.it

\$ DEMS - University of Milan-Bicocca, Piazza dell'Ateneo Nuovo 1, 20126 Milan (Italy). E-mail address: nicola.pontarollo@unimib.it
} 


\section{Introduction}

In the last fifteen years, Italy has known a dramatic increase in immigrant population, rising from just over one million (3.04 per cent of total population) in 2001 to 4.9 million (8.1 per cent of total population) at the beginning of 2014. Historically, migrants arriving in Italy have all tended to settle mainly in the North and Centre provinces, but their characteristics as well as their distribution across productive sectors have always been quite heterogeneous. According to INEA (2009), 3.9 per cent of foreign residents are employed in the agricultural sector, 40.9 per cent in the industrial sector, and 55 per cent in services. While a growing literature analyses the impact of total immigrant inflows on the economic growth of the host country, almost none distinguish ethnic minorities on the basis of their spatial distribution. Among the more recent contributions, Kangasniemi et al. (2012) and Nicodemo (2013) find a negative impact on productivity level for Spain, a country that, like Italy, experienced a productivity reduction in the last years. On the contrary, Rolfe et al. (2013) find a positive effect of migrants (not distinguished by ethnicity) on the whole productivity growth for the United Kingdom, which seems able to attract skilled people from abroad. Other studies, such as Alesina et al. (2003), Easterly and Levine (1997), Montalvo and Reynal-Querol (2005) and Gören (2014), focus on the effect of ethnic fragmentation on economic growth. Barro and McCleary (2003), Noland (2005), and Sala-i-Martin et al. (2004), finally, investigate the relationship between different religions and economic performance.

In this paper, we shift the analysis on foreign groups of different nationalities, which are clustered in space and tend to be specialised in certain occupations. The aim is to investigate whether and to what extent ethnic minorities contribute to Italian productivity growth in five key sectors: agriculture, industry, construction, high services (office and professional work), and low-services (wholesale, retail, hotels and catering, transport and distribution, housework). 
To this purpose, we consider the first ten nationalities by numbers of regularised persons, according to the latest 2011 census data, which account for the 63.79 per cent of the total foreign population residing in Italy. ${ }^{1}$ They are observed at the provincial level (NUTS-3) from 2003 to 2011. We use an empirical growth model with spatially augmented specifications, which captures both the direct (marginal) and indirect (spillover) effects of each community on the productivity growth rate. To our best knowledge, the specific contribution to local productivity of foreign groups and the effect due to their spatial distribution have not yet been empirically investigated, then this work is a first attempt to provide some meaningful results for the Italian case. Our findings show that two communities out of ten have a positive impact on Italian economic performance. They are from Philippines and Poland, specialised in health care services, child care, housing services. Romanian, Marroquin and Tunisian, instead, have significant indirect effects, which imply that these groups do not affect growth of provinces in which are settled, but affect growth of neighbouring provinces likely because of commuting. The paper is organised as follows. Section 2 presents an overview of recent trends in foreign migration across Italian provinces. Section 3 introduces the empirical growth model with spatially augmented specifications. Section 4 shows the results and Section 5 concludes.

\section{Ethnic minorities in Italy}

Italy has experienced mass immigration relatively recently, since $2000 .^{2}$ The largest ethnic group was from Morocco in 2001, followed by Albania and Romania and nowadays those

\footnotetext{
${ }^{1}$ Foreigners from other countries are less than 100,000 per country and were excluded from the analysis because in terms of percentage over the total population are too few.

${ }^{2}$ Actually Italy has seen significant inflows of immigrants from Albania since 1991, after the collapse of the Communist bloc, and one year earlier, in 1990, a first law was approved trying to regulate the entry flows, as well as to introduce an immigration amnesty for about 200,000 foreigners, mainly from North Africa, who were already in Italian territory. However, the number of foreign residents is less than one million until 1997 over a total population of 56 million inhabitants, then less of 1.7 in percentage terms.
} 
countries continue to be the most represented with only a slight change in the ranking: Romania became first since 2007, Albania second and Morocco third. Other groups more represented come from Asia (in particular from China and Philippines), North-Africa (Tunisia, in addition to Morocco) East-Europe (Albania, Romania, Moldova, Poland, Ukraine). According to official statistics and statistical surveys by Leone Moressa Foundation (2012), foreign people usually work in low-skilled positions concentrated in three sectors: agriculture, construction and lowservices. Table 1 reports the specialisation of the first 10 nationalities determined by the largest employment share of each community across sectors.

\begin{tabular}{llc}
\hline \hline Country & Specialisation & Occupied (\%) \\
\hline Albania & Construction & 27.5 \\
Romania & low-services (in particular housing and personal services) & 25.2 \\
China & commercial sector & 48.7 \\
Philippines & low-services (in particular housing and personal services) & 77.4 \\
Morocco & Construction & 14.1 \\
Moldova & low-services (in particular housing and personal services) & 46 \\
Poland & low-services (in particular health care, housing and personal services) & 37.2 \\
Tunisia & Construction & 19.5 \\
Ukraine & low-services (in particular health care, housing and personal services) & 67.2 \\
India & Agriculture & 16.3 \\
\hline \hline
\end{tabular}

*Source: Leone Moressa Foundation (2012)

Table 1: ethnic community specialisation

Some ethnic groups are much more specialised than others. Among the more specialised there are the groups from Philippines, Ukraine and China. The most fragmented groups are from India, Morocco, Tunisia, Albania and Romania. Regarding the main occupations, people from Albania, Morocco and Tunisia are mainly employed in the construction sector; people from Poland, Ukraine, Moldova and Philippines in health care services, child care, personal and housing services; people from China have a strong presence in the commerce, specifically in the textile and clothing sector. People from India are employed in the agriculture sector, as well as a significant percentage of Tunisians (11.7 per cent).

The distribution of foreign groups is observed in 103 Italian provinces (NUTS-3), which is the 
lowest possible disaggregation for which data are available. The period of observation is between 2003 and $2011 .^{3}$ Data on foreign residents by nationality come from the Italian National Statistical Institute (ISTAT) and are about foreigners regularly registered. ${ }^{4}$ Data on sectoral employment and Gross Value Added (GVA) at the provincial level for the period 20032011 are from Cambridge Econometrics Database. ${ }^{5}$ GVA is in real terms, with base year 2005. Table 2 reports the correlation between initial (year 2003) GVA per employee for each of the six sectors and share of immigrants. The correlation is generally low and positive, meaning that there is a weak tendency for immigrants to settle in provinces in which the sectoral GVA per employee is high. There are few cases showing a correlation above 0.20 . The sector with the highest correlation is agriculture for people coming from Albania and construction for Albania and Marroquins, with 0.24 and 0.30 , respectively. We observe a negative correlation between initial GVA per employee in low-level services for all the nationalities, with the exception of India. Initial GVA per employee in high-level services shows a negative correlation in half cases, while the GVA per employee in the construction sector has a negative correlation in three cases.

\begin{tabular}{lcccccc}
\hline \hline & Total & Agriculture & Industry & Construction & $\begin{array}{c}\text { High lev. } \\
\text { services }\end{array}$ & $\begin{array}{c}\text { Low lev. } \\
\text { services }\end{array}$ \\
\hline Albania & 0.3007 & 0.4679 & 0.1769 & 0.2402 & 0.1067 & -0.1269 \\
Romania & 0.1597 & 0.2459 & 0.1028 & -0.0356 & -0.1243 & -0.1208 \\
China & 0.1347 & 0.2249 & 0.1202 & 0.0756 & -0.0149 & 0.0185 \\
Philippines & 0.2322 & 0.2731 & 0.1809 & 0.0718 & -0.0658 & -0.1623 \\
Morocco & 0.3416 & 0.3118 & 0.2662 & 0.2925 & 0.0867 & -0.0147 \\
Moldova & 0.1616 & 0.2262 & 0.1376 & 0.1355 & 0.0157 & -0.0802 \\
Poland & -0.1137 & 0.0479 & -0.2186 & -0.3579 & -0.1900 & -0.1786 \\
Tunisia & 0.1311 & 0.1944 & 0.0648 & 0.0776 & 0.1032 & -0.0643 \\
\hline
\end{tabular}

${ }^{3}$ In the half 2005, four new provinces were created in Sardinia region: Carbonia-Iglesias, Medio Campidano; Ogliastra, Olbia-Tempio. As for these provinces there are missing data, and bilateral migration flows were very little, we reassigned each of these new provinces to the province in which it was originally incorporated. Data about Carbonia-Iglesias and Medio Campidano were reassigned to Cagliari; data about Ogliastra were reassigned to Nuoro; data about Olbia-Tempio were reassigned to Sassari.

${ }^{4} \mathrm{We}$ are aware that we do not observe the total amount of foreigners because of lack of official data about irregular immigrants by province. Accordingly, our analysis implicitly assumes that irregular migrants do not contribute effectively to productivity.

${ }^{5}$ Cambridge Econometrics database is complete while data from ISTAT contain a great number of missing values for sectoral employment and GVA at the provincial level. 


\begin{tabular}{lcccccc}
\hline Ukraine & 0.1345 & 0.2356 & 0.0564 & -0.0257 & -0.2406 & -0.1565 \\
India & 0.1981 & 0.2405 & 0.1486 & 0.1779 & 0.0357 & 0.0838 \\
\hline
\end{tabular}

Table 2: correlation matrix between sectoral GVA per employee and share of immigrants by nationality

Figure 1 reports on the left axis the variance of the share of foreigners in total population and on the right axis their spatial concentration across provinces measured through Moran's I over time, that correlates the value of a variable with the value of the same variable in neighbour provinces. 6

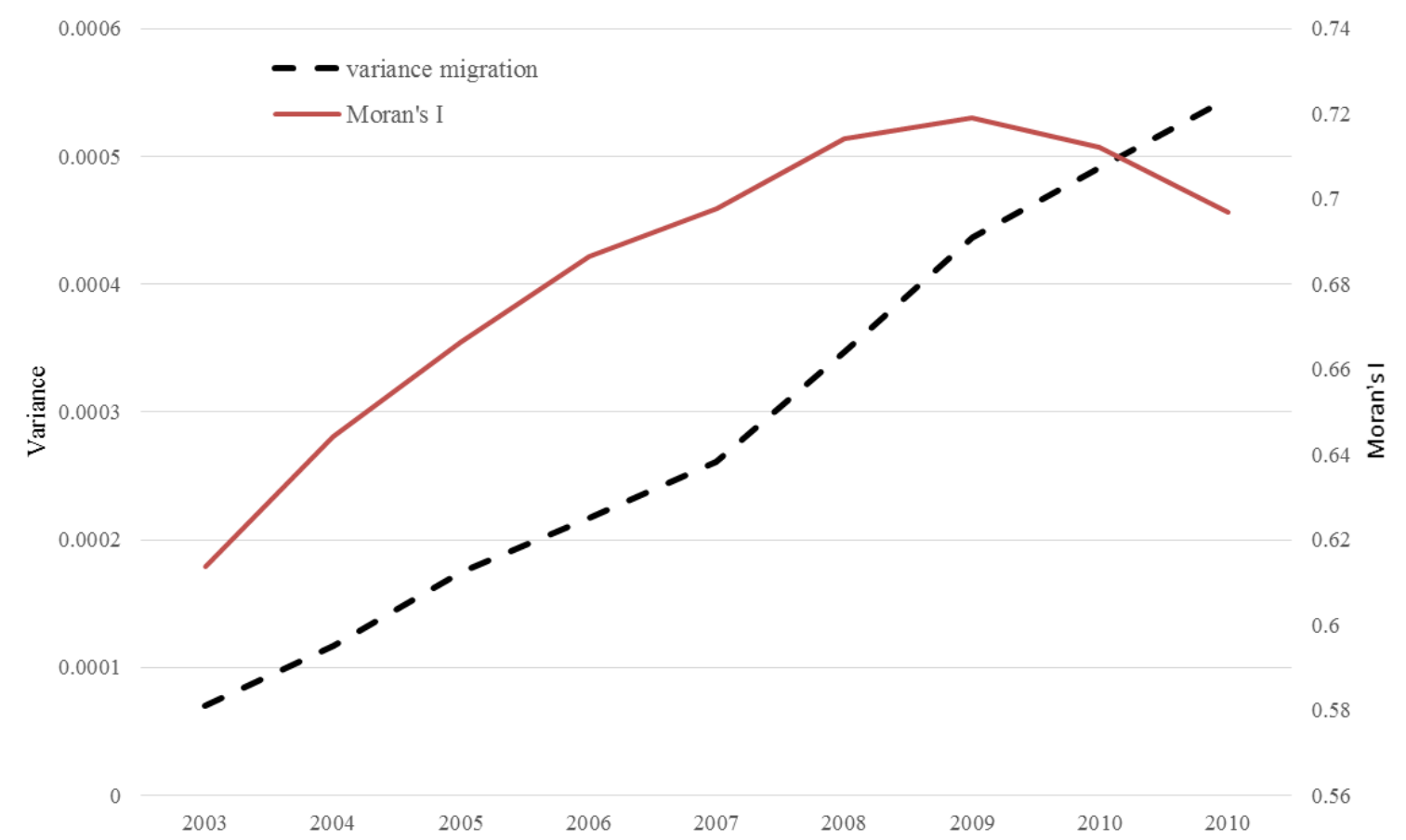

Figure 1: variance and Moran's I of total foreigners over population

The insights from this graph are threefold. First, there is a very strong evidence of spatial dependence, as the p-value, not reported in the graph, is always lower than 0.01 for all years. Migration phenomenon tends to be clustered in nature, with provinces having relatively high

${ }^{6}$ Moran's I is defined as: $M I=\frac{N}{\sum_{i=1}^{N} \sum_{j=1}^{N} w_{i, j}} \frac{\sum_{i=1}^{N} \sum_{j=1}^{N} w_{i, j}\left(y_{i}-\bar{y}_{i}\right)\left(y_{j}-\bar{y}_{j}\right)}{\sum_{i=1}^{N}\left(y_{i}-\bar{y}_{i}\right)}$

where $N$ is the number of provinces indexed by $i$ and $j ; y$ is the share of foreigners in total population; $w_{i, j}$ is an element of a queen weights matrix $\mathbf{W}$ of $N \times N$ size. The calculated Moran's I for global autocorrelation varies between -1 and 1. A positive (negative) coefficient corresponds to a value of Moran's I that is larger (lower) than its theoretical mean equal to -1/N-1, or, equivalently, a positive (negative) $z$-value, and points to positive (negative) spatial autocorrelation, i.e. similar (dissimilar ) values cluster together in a map. 
(low) percentage of foreign population that are located near others with high (low) percentage of foreign population. Most spatially concentrated foreign groups are from Albania, Romania, Morocco, Poland and Ukraine, with Moran's I between 0.40 and 0.62 . The less concentrated foreign groups are from Philippines, Tunisia, Moldova and India, with a Moran's I between 0.10 and 0.32 . The Moran's I is not statistically significant for people from China, which are widespread over space. The clusterization of foreign communities, found also by González and Ortega (2011) for Spain, is likely driven by at least three factors: the presence of people of the same community already settled down in a given province or in the neighbour provinces, the so-called chain migration; the provincial economic conditions in terms of job opportunities; the endowments of infrastructures, local goods and services affecting the living conditions of newcomers. The clusterization implies that foreign communities in a province cannot be seen as independent from those in the other provinces. This evidence leads us to adopt an empirical strategy that takes into account the spatial dependence of community distribution across provinces.

The second interesting insight is that spatial autocorrelation is always positive and increases until 2009, meaning that foreign people tend to concentrate in space, then slightly decrease. This could be a consequence of the great recession, which affected both the location decisions of people already living in Italy and the choice of foreigners to migrate to this country.

The third insight is the co-movement between the percentage of foreign people's variance and the Moran's Index until 2009, and then a divergence between the two measures. The spatial dependence strengthens as the foreign dispersion increases implying that clusters of provinces are likely to become more similar over time with a stronger spatial pattern that is translated into an increasing variance. Since 2009 , the spatial dependence slightly weakens while the foreign dispersion continues to increase.

Since our analysis focuses on the relationship between productivity growth and ethnic minority 
concentration, we report a brief overview of productivity dynamics over the period 2003-2011. Figure 2 reports the so called $\sigma$-convergence, i.e. the dispersion of the (log) of GVA per employee and the Moran's I of the same variable over time. Also in this case there is a very strong evidence of spatial dependence in the productivity growth, which will be explicitly taken into account to define the empirical strategy in Section 3.

Notice that Moran's I is quite stable until 2007, and then sharply declines as well as the variance of the (log) GVA per employee. These patterns imply that, at least since 2008, productivity tends to be more homogeneous both in space (less clustered) and in absolute terms (less extreme values). Unfortunately, the greater degree of homogeneity between provinces is due to a loss of competitiveness of northern provinces and not to an increase of productivity in the southern provinces. Then, the result is a more equal but less competitive country (EC, 2014).

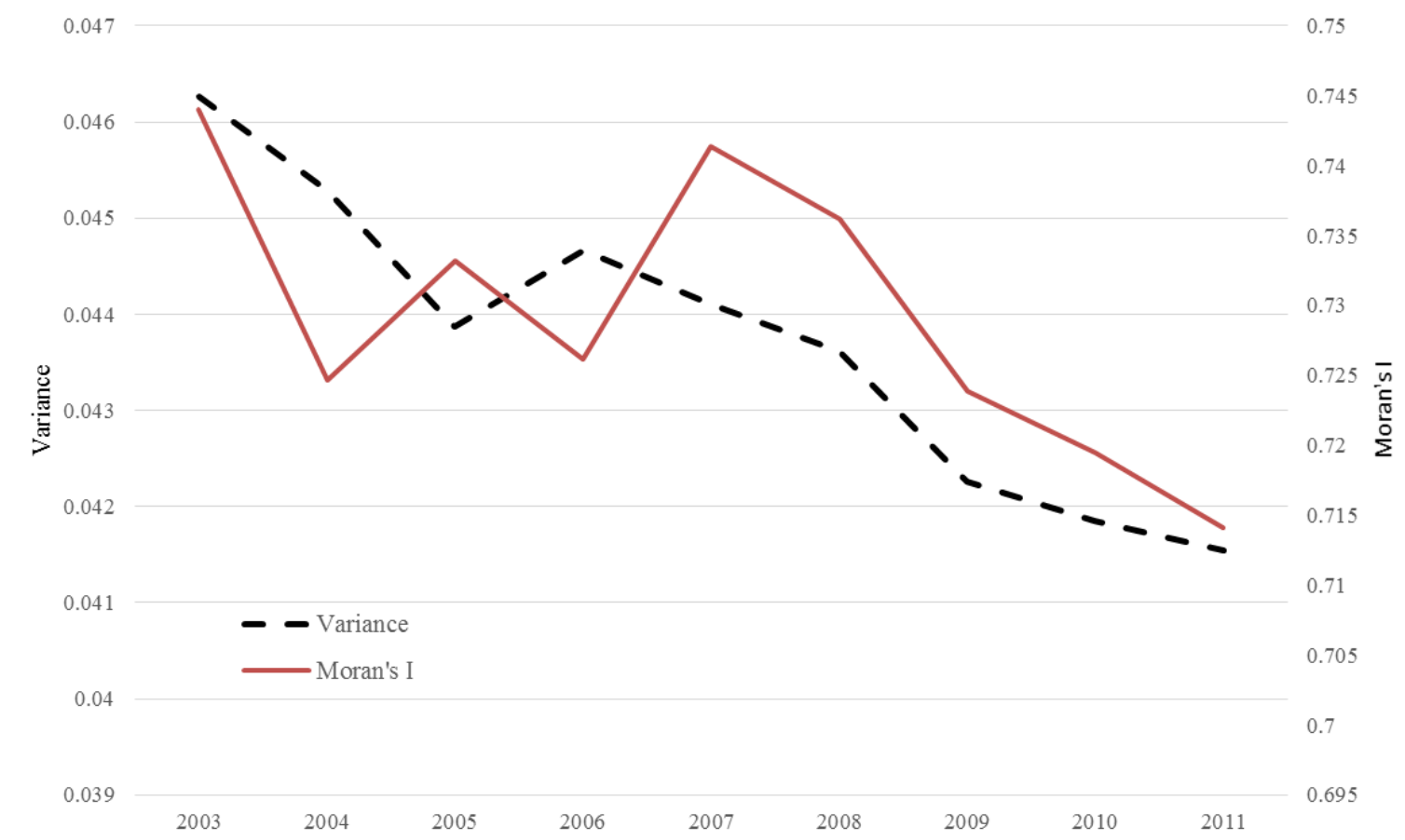

Figure 2: variance and Moran's I of $\log (\mathrm{GVA} / \mathrm{emp})$

Figure 3 depicts the relation between the annual productivity growth rate and the percentage of foreign people over the total population (observed at the beginning of each year) for the period 2003-2011. The negative association between the share of foreigners and productivity growth 
is linear and no leverage points or influent outliers are detected.

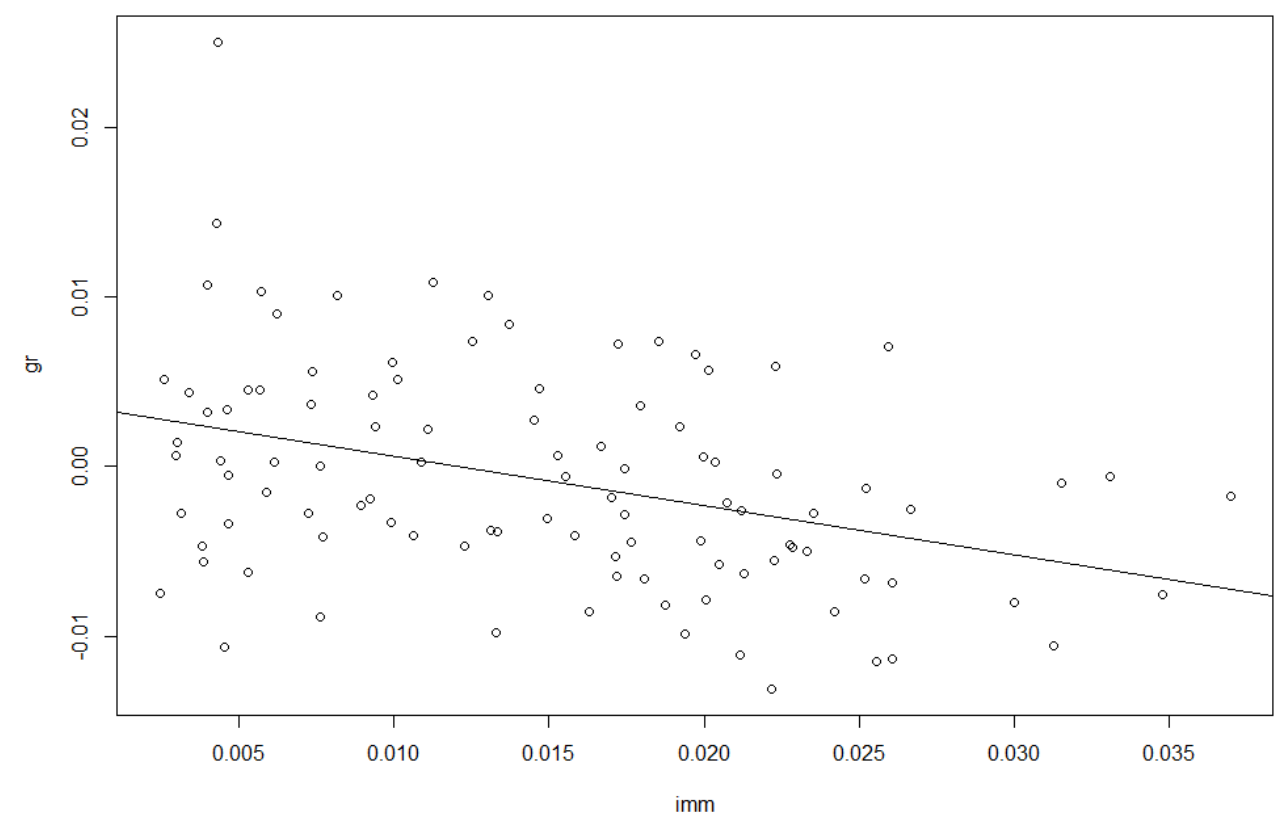

Figure 3: relation between the percentage of foreign people and the average GVA/emp growth rate, period 2003-2011.

This first analysis shows a spatial concentration of foreigners in the centre and north of Italy, which seems not to be efficient for enhancing productivity growth. In the following section we go deeper into the analysis by introducing a theoretical model and the empirical methodology to implement it.

\section{Theoretical framework and empirical methodology}

Our model can be considered to be somewhat in the spirit of the human capital model of de la Fuente and Doménech (2006) and later extended by Ramos et al. (2010). Ethnic minorities are assumed to be characterized by a combination of skills, which lead foreign people to find an employment in specific sectors. In this framework, skills are conceptualized in very general terms and they also include the capacity of foreign people to find an employment thanks to personal network with people of the same nationality. The model considers a Cobb-Douglas 
production function, expressed as follows:

$Y_{i, t}=K_{i, t}^{\alpha} H_{i, t}^{\beta}\left(A L_{i, t}\right)^{(1-\alpha-\beta)}$

where $Y$ is the output, $K$ the capital, $H$ the skills of foreign workers, $L$ the labour force and $A$ the technology. Subscripts $i$ and $t$ denote the geographical unit (province) and time.

Taking the log and dividing all variables by the effective quantity of labor, $A L_{i, t}$, we obtain:

$y_{i, t}=\alpha k_{i, t}+\beta h_{i, t}$,

where $h_{i, t}$ represents ethnic community skills per unit of effective labor. As mentioned in Section 2, we have some insights on ethnic community skills from the prevalent occupation, as reported in table 1 . This leads us to use the percentage of people of nationality $e$ over the total population as proxy for ethnic community skills per unit of effective labor. Accordingly, equation (2) becomes:

$y_{i, t}=\alpha k_{i, t}+\sum_{e=1}^{E} \beta_{i, t}^{e} h_{i, t}^{e}$

Following the approach developed by Barro (2000), Barro and Sala-i-Martin (2003), and Ramos et al. (2010), we transform equation (3) to derive convergence equation, in which growth in a province over a given period is inversely related to its initial productivity level as a result of the mechanism of convergence towards its steady state:

$g_{i, s, t}=\varphi y_{i, s, t-1}+\alpha k_{i, t-1}+\sum_{e=1}^{E} \beta_{i, t-1}^{e} h_{i, t-1}^{e}$

where, in a panel framework, the dependent variable $g_{i, t}$ represents the growth rate of GVA per employee in province $i$ between time $t$ - 1 and $t$, i.e. $y_{i, t}-y_{i, t-1}$, and $y_{s t-1}$ is the logarithm of GVA per employee in sector $s$ at time $t-1$. The inverse relation between growth in a province and its initial productivity level is given by the negative predicted sign of the parameter $\varphi$, which indicates that convergence is occurring.

Selection concern may arise since per capita GDP (correlated with productivity levels) could guide the selection of minority groups into provinces. However, the lack of systematic differences in ethnic minority shares across provinces by sector, shown in Section 2 (see table 
1) decreases the concern that per capita GDP guides the selection of ethnic minority groups.

The assumption underlying model (4) is that sectoral GVA per employee growth rate in a province is independent of sectoral GVA per employee growth rate in other provinces. However, as pointed out by Fingleton and López-Bazo (2006), growth rate in a province is likely to be influenced by economic performance in other provinces, because provinces are interdependent and we must not treat regions as "isolated islands" (Mankiw, 1995; Quah, 1996). If such spatial dependence is not taken into account in the empirical model specification, results are likely to be biased and may lead to misleading conclusions. Given the likely interdependence in economic performance across provinces, as detected in figure 3, we adopt an estimation strategy able to account for externalities across provinces' economic systems.

Equation (4) is augmented with spatially lagged dependent and independent variables, which permit to analyse the existence of geographical spillovers among foreigners from a same country located in different provinces. As LeSage and Fischer (2008) point out, the inclusion of spatially lagged independent variables also permits to overcome the problem of omitted variables. A similar specification has been used also by Ertur and Koch (2007) who develop a theoretical growth model which considers spatial externalities across regions, as well as by Ramos et al. (2010) for measuring geographical spillovers of human capital.

The empirical model, known as Spatial Durbin, is as follows:

$g_{i, s, t}=\vartheta+\rho \mathbf{W} g_{i, s, t}+\varphi y_{i, s, t-1}+\sum_{e=1}^{E} \beta_{i, t-1}^{e} h_{i, t-1}^{e}+\eta \mathbf{W} y_{i, s, t-1}+\mathbf{W} \sum_{e=1}^{E} \theta_{i, t-1}^{e} h_{i, t-1}^{e}+$

$\sum_{p=1}^{N-1} \varphi_{p} D_{p}+\sum_{\tau=1}^{T-1} \gamma_{\tau} D_{\tau}+\varepsilon_{i s t}$

where $\mathbf{W}$ is the spatial weights matrix defined in footnote $3 . \vartheta$ is a constant term; $D_{p}$ and $D_{\tau}$ are dummy variables such that $D_{p}=1$ and $D_{t}=1$ if $p=i$ and $\tau=t$, respectively, and $D_{p}=$ 0 and $D_{\tau}=0$ otherwise. Provincial and time dummy variables control for unvarying factors determining differences in the steady states across provinces. $\varepsilon_{i, s, t}$ is the usual error term. In our empirical application, we estimate model (5) for five sectors: agriculture, industry, construction, 
high level services and low level services.

Model (5) introduces a dependence among provinces' economic systems in form of global externalities: a shock in province $i$ is transmitted to its neighbours by parameter $\rho$ that, in turn, is transmitted again to province $i$ through $\mathbf{W}$, reinitiating the process until the effect becomes negligible for $N$ that tends to infinite (LeSage and Fischer, 2008).

One of the advantages of Spatial Durbin model, whose choice is statistically funded as we will see in Section 4, is the possibility to express the impact on the dependent variable (GVA per employee growth rate) from a change in one the independent variables as a combination of direct and indirect neighbourhood influences (LeSage, 2008). While direct effects are related to the well know notion of marginal effect, like in standard regression models, the interpretation of the indirect effects is related to spatial spillovers. This is due to the presence of the spatial autoregressive parameter $\rho$ and the parameter associated with the spatial lags of the independent variables. Thus, taking the partial derivative of the variable $h_{i, t-1}^{e}$, we have:

$\frac{\partial g_{i, s, t}}{\partial h_{i, t-1}^{e}}=(\boldsymbol{I}-\rho \mathbf{W})^{-1}\left(\mathbf{I} \beta_{i, t-1}^{e}+\theta_{i, t-1}^{e} \mathbf{W}\right)$

LeSage and Pace (2009a, 2009b) define the average direct effect as the average of the diagonal elements of (6), and the average indirect effect as the average of the off-diagonal elements, where the off-diagonal row elements are first summed up, and then an average of these sums is taken. Finally, the sum of the direct and indirect effects gives the average total effect.

The key parameter through which spatial spillovers effects are transmitted to the whole economy is $\rho$. It enters in the spatial multiplier $(\boldsymbol{I}-\rho \mathbf{W})^{-1}$ that defines the strength of the linkage between the productivity growths of the neighbouring provinces. An estimated positive value for the parameter $\rho$ means that the spatial multiplier amplifies the effects of a change in surrounding provinces with respect to the productivity growth of the original province. On the contrary, an estimated negative value for $\rho$ implies that a province does not fully exploit, in 
terms of productivity growth, a variation of a variable in the neighbouring provinces.

In order to estimate Spatial Durbin Model, we use the Maximum Likelihood (ML) approach proposed by Elhorst (2014). Comparing this estimation methodology with the one of Kelejian et al. (2006) which uses Instrumental Variables/Generalised Method of Moments (IV/GMM), one advantage is that instruments usually include spatially lagged independent variables, a requirement that will not permit to test the influence of spatial spillovers in the fashion of LeSage and Pace (2009a, 2009b).

We conclude this section with some further comments supporting the choice of the spatial Durbin model. The choice of the spatial model to use for the empirical analysis may be based on two different approaches: a specific-to-general approach and a general-to-specific approach. In the first case, the selection between the spatial lag and spatial error model is done through a (robust) Lagrange Multiplier (LM) test performed on OLS estimates. Nevertheless, Elhorst (2010) suggests that if LM tests for spatial lag and error are both significant the next step should be to estimate the spatial Durbin model. This is also suggested by LeSage and Pace (2009a) observing that, as the choice of spatial error model could hide misspecification problems (Fischer and LeSage, 2008), a solution is to choose the spatial Durbin model. The second approach, following LeSage and Pace (2009a), checks the spatial Durbin model against more simple models using a Lagrange Ratio (LR) and a Wald test. In the next section, we show the results of the tests used in the two approaches and we will see that they support the choice of the spatial Durbin model for our analysis.

\section{Results}

Table 2 reports the results of the tests used in the specific to general approach. A Lagrange Multiplier (LM) test and a robust LM test are carried out on the residuals of an OLS regression. 
The outcomes lead us to reject the hypothesis of absence of spatial autocorrelation in the residuals of all the five equations (one for sector). Moreover, following Elhorst (2010), we expect to obtain more reliable estimates by considering a spatial Durbin model accounting for spatial autocorrelation.

\begin{tabular}{lrrrrrr}
\hline & Total & Agriculture & Industry & Const. & $\begin{array}{r}\text { High lev. } \\
\text { services }\end{array}$ & $\begin{array}{r}\text { Low lev. } \\
\text { services }\end{array}$ \\
\hline LM test sp. Lag & 47.631 & 71.124 & 40.625 & 205.976 & 206.802 & 100.857 \\
& $(<0.01)$ & $(<0.01)$ & $(<0.01)$ & $(<0.01)$ & $(<0.01)$ & $(<0.01)$ \\
Robust LM test & 0.568 & 5.5018 & 3.863 & 6.162 & 15.169 & 0.042 \\
sp. Lag & $(0.451)$ & $(0.019)$ & $(0.049)$ & $(0.013)$ & $(<0.01)$ & $(0.837)$ \\
LM test sp. Error & 49.403 & 66.895 & 36.854 & 213.013 & 192.857 & 112.728 \\
& $(<0.01)$ & $(<0.01)$ & $(<0.01)$ & $(<0.01)$ & $(<0.01)$ & $(<0.01)$ \\
Robust LM test sp. & 2.339 & 1.273 & 0.093 & 13.199 & 1.225 & 11.913 \\
Error & $(0.126)$ & $(0.259)$ & $(0.76)$ & $(<0.01)$ & $(0.268)$ & $(<0.01)$ \\
\hline \hline
\end{tabular}

p-values in brackets.

Table 2: Test for model selection on OLS residuals 
The estimates of the spatial Durbin model, given by (5), are reported in table 3. Column 2 contains the estimated coefficient associated with the GVA per employee for the whole economy, while columns 3 to 7 contain the results for the five sectors: agriculture, industry, construction, high services, and low services.

At the end of table 3, the tests used in the general-to-specific approach are reported. The Wald and LR tests clearly discriminate in favour of the spatial Durbin model for four out of six cases, i.e. whole economy, agriculture, industry and construction. The best model for high-services is spatial lag, while for low-services is spatial error. ${ }^{7}$ Furthermore, the highly significant $\rho$ parameter, which ranges between 0.24 and 0.52 confirms the presence of positive spatial spillovers.

According the F-test results, foreign groups are jointly significant with the exception of highservices $(p$-value $=0.38)$; for low-services foreign groups are statistically significant at the 0.1 level. The results for Hausman test supports the choice of using a within model with spatial and temporal dummies rather than a random effect model. Finally, as the time span of our sample goes from 2003 to 2011, including the pre- and post- great recession years, we performed a Chow test for 2008 in order to verify if a structural break is present in that year. The results confirm the structural break, which is consistent with the pattern of Moran's I (see Figure 1), which slightly decreases since 2009 .

\footnotetext{
${ }^{7}$ The results for these two models are consistent with the estimates of the spatial Durbin and are available upon request.
} 


\begin{tabular}{|c|c|c|c|c|c|c|c|}
\hline & Total & & Agriculture & Industry & Construction & High lev. services & Low lev. services \\
\hline \multirow[t]{2}{*}{ GVA/emp } & -0.27150 & $* * *$ & $-0.40316 * * *$ & $-0.25732 * * *$ & $-0.37327 * * *$ & $-0.16321 * * *$ & $-0.15431 * * *$ \\
\hline & $(-11.50576)$ & & $(-15.2055)$ & $(-10.34615)$ & $(-13.49658)$ & $(-13.95747)$ & $(-12.32107)$ \\
\hline \multirow[t]{2}{*}{ Albania } & -0.06395 & & $-8.74093 * *$ & $3.14852 *$ & -1.70997 & -0.95731 & 1.23424 \\
\hline & $(-0.11481)$ & & $(-2.272)$ & $(1.86195)$ & $(-0.9331)$ & $(-1.14899)$ & $(1.07716)$ \\
\hline \multirow[t]{2}{*}{ Romania } & -0.47380 & $*$ & -0.81529 & -0.47016 & 0.66268 & 0.19088 & -0.21735 \\
\hline & $(-1.81272)$ & & $(-0.45509)$ & $(-0.59644)$ & $(0.77311)$ & $(0.49301)$ & $(-0.40308)$ \\
\hline \multirow[t]{2}{*}{ Cina } & -1.13181 & $* * *$ & 0.55495 & $-3.86719 * * *$ & -1.50185 & -0.51123 & 1.3228 \\
\hline & $(-2.83442)$ & & $(0.20281)$ & $(-3.21339)$ & $(-1.14571)$ & $(-0.86552)$ & $(1.6068)$ \\
\hline \multirow[t]{2}{*}{ Philippines } & 3.75334 & & -13.29916 & 8.07580 & -5.41252 & $5.94870 *$ & $10.22763 * *$ \\
\hline & $(1.60679)$ & & $(-0.83571)$ & $(1.15996)$ & $(-0.71056)$ & $(1.71277)$ & $(2.03300)$ \\
\hline \multirow[t]{2}{*}{ Morocco } & -0.94144 & & 1.77459 & -2.54559 & -2.62100 & 1.41940 & 2.27631 \\
\hline & $(-1.0334)$ & & $(0.28569)$ & $(-0.91719)$ & $(-0.87949)$ & $(1.05565)$ & $(1.22481)$ \\
\hline \multirow[t]{2}{*}{ Moldova } & -2.30516 & $* * *$ & -4.12452 & -2.96534 & $-7.67674 * * *$ & -1.15058 & $-2.91762 * *$ \\
\hline & $(-3.31057)$ & & $(-0.87038)$ & $(-1.42175)$ & $(-3.33494)$ & $(-1.11559)$ & $(-2.04768)$ \\
\hline \multirow[t]{2}{*}{ Poland } & 6.03618 & $* * *$ & $70.99639 * * *$ & 0.44537 & $-17.18948 * * *$ & $4.97747 *$ & 4.54292 \\
\hline & $(3.42154)$ & & $(5.7564)$ & $(0.08429)$ & $(-2.98526)$ & (1.91953) & (1.26477) \\
\hline \multirow[t]{2}{*}{ Tunisia } & 1.29320 & & 1.26689 & -0.46726 & 2.85185 & -2.06269 & -2.73987 \\
\hline & $(0.91644)$ & & $(0.13042)$ & $(-0.10845)$ & $(0.61723)$ & $(-0.99393)$ & $(-0.95189)$ \\
\hline \multirow[t]{2}{*}{ Ukraine } & -2.61392 & $* *$ & -7.68075 & $-10.45095 * * *$ & -2.55930 & 1.42664 & -3.17258 \\
\hline & $(-2.45194)$ & & $(-1.05646)$ & $(-3.25529)$ & $(-0.73338)$ & $(0.90458)$ & $(-1.4492)$ \\
\hline \multirow[t]{2}{*}{ India } & -1.26767 & $*$ & -5.13192 & -2.67668 & 0.58108 & $-1.99369 *$ & 0.27559 \\
\hline & $(-1.71483)$ & & $(-1.02426)$ & $(-1.20021)$ & (0.24019) & $(-1.83748)$ & $(0.1833)$ \\
\hline \multirow[t]{2}{*}{$\mathrm{W} \times \mathrm{GVA} / \mathrm{emp}$} & 0.03213 & & $0.12311 * *$ & -0.05380 & 0.07242 & -0.00613 & $0.07202 * * *$ \\
\hline & $(0.7821)$ & & $(2.40202)$ & $(-1.09598)$ & (1.53904) & $(-0.24423)$ & $(3.21553)$ \\
\hline \multirow[t]{2}{*}{ W×Albania } & 0.90602 & & $15.30395 * *$ & -1.04486 & 4.32990 & 2.13488 & 0.68029 \\
\hline & $(0.97993)$ & & (2.40477) & $(-0.37021)$ & $(1.42280)$ & $(1.55487)$ & $(0.35662)$ \\
\hline \multirow[t]{2}{*}{$\mathrm{W} \times$ Romania } & -1.08556 & $* *$ & -4.66033 & -1.25633 & 0.66080 & $-1.43127 * *$ & -1.33666 \\
\hline & $(-2.34054)$ & & $(-1.48451)$ & $(-0.91051)$ & $(0.43962)$ & $(-2.08079)$ & $(-1.38449)$ \\
\hline \multirow[t]{2}{*}{$\mathrm{W} \times$ Cina } & -0.51110 & & $11.29027 *$ & 2.36998 & 0.57013 & -1.16095 & 0.79837 \\
\hline & $(-0.59132)$ & & $(1.89455)$ & $(0.91172)$ & $(0.19928)$ & $(-0.90769)$ & $(0.44853)$ \\
\hline
\end{tabular}




\begin{tabular}{|c|c|c|c|c|c|c|}
\hline W $\times$ Philippines & $\begin{array}{r}5.29540 \\
(1.10382)\end{array}$ & $\begin{array}{l}58.48539 * \\
(1.82544)\end{array}$ & $\begin{array}{r}-9.49900 \\
(-0.67393)\end{array}$ & $\begin{array}{r}-2.36805 \\
(-0.15445)\end{array}$ & $\begin{array}{r}8.42906 \\
(1.18102)\end{array}$ & $\begin{array}{l}-23.70338 * * \\
(-2.41807)\end{array}$ \\
\hline $\mathrm{W} \times$ Morocco & $\begin{array}{l}3.15108 * * \\
(2.20329)\end{array}$ & $\begin{array}{l}15.14869 \\
(1.54535)\end{array}$ & $\begin{array}{l}14.83392 * * * \\
(3.38955)\end{array}$ & $\begin{array}{l}-4.97192 \\
(-1.0633)\end{array}$ & $\begin{array}{r}-1.57140 \\
(-0.73583)\end{array}$ & $\begin{array}{r}-1.81930 \\
(-0.62096)\end{array}$ \\
\hline W×Moldova & $\begin{array}{r}-0.29855 \\
(-0.22517)\end{array}$ & $\begin{array}{l}-16.08849 * \\
(-1.76076)\end{array}$ & $\begin{array}{r}2.18830 \\
(0.54573)\end{array}$ & $\begin{array}{r}2.48697 \\
(0.56943)\end{array}$ & $\begin{array}{r}-0.59847 \\
(-0.30417)\end{array}$ & $\begin{array}{r}-3.77120 \\
(-1.37986)\end{array}$ \\
\hline $\mathrm{W} \times$ Poland & $\begin{array}{r}1.20311 \\
(0.43731)\end{array}$ & $\begin{array}{l}-46.65583 * * \\
(-2.40714)\end{array}$ & $\begin{array}{l}10.48269 \\
(1.25762)\end{array}$ & $\begin{array}{r}-2.69546 \\
(-0.29518)\end{array}$ & $\begin{array}{r}-2.91991 \\
(-0.71518)\end{array}$ & $\begin{array}{r}-0.81518 \\
(-0.14537)\end{array}$ \\
\hline WxTunisia & $\begin{array}{l}-8.55744 * * * \\
(-3.41606)\end{array}$ & $\begin{array}{l}-35.59997 * * \\
(-2.08417)\end{array}$ & $\begin{array}{l}-30.61194 * * * \\
(-3.97226)\end{array}$ & $\begin{array}{l}-18.07641 * * \\
(-2.17615)\end{array}$ & $\begin{array}{r}0.50796 \\
(0.13771)\end{array}$ & $\begin{array}{r}4.89316 \\
(0.96032)\end{array}$ \\
\hline W $\times$ Ukraine & $\begin{array}{r}3.17811 \\
(1.63905)\end{array}$ & $\begin{array}{r}-6.53509 \\
(-0.48870)\end{array}$ & $\begin{array}{l}10.01052 * \\
(1.71518)\end{array}$ & $\begin{array}{l}12.05217 * \\
(1.88215)\end{array}$ & $\begin{array}{r}-0.24823 \\
(-0.08655)\end{array}$ & $\begin{array}{r}3.03400 \\
(0.76298)\end{array}$ \\
\hline WxIndia & $\begin{array}{r}2.06564 \\
(1.51069)\end{array}$ & $\begin{array}{r}7.27855 \\
(0.77774)\end{array}$ & $\begin{array}{r}-4.14301 \\
(-0.98743)\end{array}$ & $\begin{array}{l}12.19431 * * \\
(2.55401)\end{array}$ & $\begin{array}{l}4.24021 * * \\
(2.05701)\end{array}$ & $\begin{array}{l}3.62961 \\
(1.2802)\end{array}$ \\
\hline$\rho$ & $\begin{array}{l}0.27773 * * * \\
(6.55592)\end{array}$ & $\begin{array}{l}0.32960 * * * \\
(8.08674)\end{array}$ & $\begin{array}{l}0.24168 * * * \\
(5.58545)\end{array}$ & $\begin{array}{r}0.52513 \text { *** } \\
(15.80004)\end{array}$ & $\begin{array}{r}0.47259 \text { *** } \\
(13.33329)\end{array}$ & $\begin{array}{rl}0.41321 & * * * \\
(10.89081) & \end{array}$ \\
\hline $\begin{array}{l}\text { R-squared (adj.) } \\
\text { sigma^2 }{ }^{\prime}\end{array}$ & $\begin{array}{l}0.7397(0.1976) \\
0.0002\end{array}$ & $\begin{array}{l}0.5003(0.2825) \\
0.0071\end{array}$ & $\begin{array}{l}0.7659(0.1792) \\
0.0014\end{array}$ & $\begin{array}{l}0.6046(0.2663) \\
0.0016\end{array}$ & $\begin{array}{l}0.7324(0.2407) \\
0.0003\end{array}$ & $\begin{array}{l}0.7537(0.2049) \\
0.0006\end{array}$ \\
\hline N. obs. & \multicolumn{6}{|c|}{824} \\
\hline log-likelihood & 2505.4568 & 914.42352 & 1595.719 & 1497.0279 & 2159.4645 & 1901.5872 \\
\hline F-test & $3.33(<0.01)$ & $3.45(<0.01)$ & $3.62(<0.01)$ & $2.24(<0.01)$ & $1.07(0.38)$ & $1.42(0.10)$ \\
\hline Chow test & $991.23(<0.01)$ & $1201.4(<0.01)$ & $1036.00(<0.01)$ & $1112.7(<0.01)$ & $1120.1(<0.01)$ & $1169.2(<0.01)$ \\
\hline F-test on ethnic groups & $305.58(<0.01)$ & $209.58(<0.01)$ & $264.94(<0.01)$ & $151.08(<0.01)$ & $84.18(<0.01)$ & $148.45(<0.01)$ \\
\hline Time fixed effects & Yes & Yes & Yes & Yes & Yes & Yes \\
\hline Provincial fixed effects & Yes & Yes & Yes & Yes & Yes & Yes \\
\hline Wald spatial lag & $28.94(<0.01)$ & $36.26(<0.01)$ & $37.07(<0.01)$ & $26.61(<0.01)$ & $13.79(0.24)$ & $23.38(0.01)$ \\
\hline LR spatial lag & $32.84(<0.01)$ & $40.24(<0.01)$ & $45.59(<0.01)$ & $28.78(<0.01)$ & $15.40(0.16)$ & $25.21(0.01)$ \\
\hline Wald spatial error & $26.03(<0.01)$ & $33.13(<0.01)$ & $36.95(<0.01)$ & $19.72(0.05)$ & $18.26(0.07)$ & $13.70(0.25)$ \\
\hline LR spatial error & $30.52(<0.01)$ & $39.49(<0.01)$ & $42.99(<0.01)$ & $21.73(0.03)$ & $19.37(0.05)$ & $15.35(0.17)$ \\
\hline Hausman test & $305.58(<0.01)$ & $209.58(<0.01)$ & $264.94(<0.01)$ & $151.08(<0.01)$ & $84.18(<0.01)$ & $148.45(<0.01)$ \\
\hline
\end{tabular}


Table 3: estimation results of Spatial Durbin regression 
The marginal effects given by equation (6), are reported in table 4. Summing up the indirect effects, the average total impacts become much more greater than the direct effects alone because of the indirect effects, which represent the average of the sum of the indirect effect coming from all neighbouring (and neighbouring of the neighbour) provinces. The indirect effects are the results of the coefficients of the spatially lagged dependent variable, which determine the magnitude of spatial spillovers, and of the spatially lagged explanatory variables, which determine the agglomeration degree.

The impact of Polish ethnic group is positive and statistically significant with respect to the total productivity growth in its direct and total effects. This means that, on one hand, the direct impact is so strong that it spreads out over the whole economy. The absence of indirect effect, on the other hand, highlights that a "cluster" effect is not present with respect to productivity growth, i.e. this ethnic group is efficient by itself and not because it is clustered in space. The positive impact is due to the positive influence on agricultural GVA per worker growth that overcomes the negative one in the construction sector. The positive impact in agriculture sector is rather interesting because the percentage of foreign people employed in this sector is only $5.3 \%$ in 2006 (INEA, 2009), but it correspond to around $20 \%$ of total occupation in this sector, with a strong variation between regions (INEA, 2009). As we mentioned in the Introduction, a small percentage of total foreigners (3.9\%) are employed in the agricultural sector, yet they represent a very important source for this sector. The positive contribution of Polish group to this sector reflects an efficient distribution of Polish people across provinces. In other terms demand and supply match in agricultural sector. The opposite holds in the construction sector since we observe a not statistically significant coefficient associated with the indirect effect. This implies that the spatial distribution of Polish community is less efficient in this sector than in the agricultural one.

The other foreign groups negatively contribute to productivity growth rate. For example, the 
strong negative effect of the Romanian community is due to the negative role in agricultural and high-services sectors, while it is surprising that it is not statistically significant in lowservices sector, where there is the highest concentration of Romanian workers. Chinese community has a direct and total negative significant effect on productivity growth due essentially to the direct negative effect in the industrial sector. Filipino community plays a weak role on whole productivity growth, but has a positive direct impact on high-services sector. This result may not be due to the direct employment of Filipinos in this sector, since they are typically specialised in low-services, as to the fact that they allow to high skilled workers to concentrate on their work making them free from housework and childcare chores. People from Morocco have an indirect positive impact on the whole productivity rate due to the indirect and total positive effect in industry, which proves that people belonging to this country do not tend to live where they work but commute, generating, as a consequence, an indirect effect. Moldovan people look like to be the less productive. Their direct and indirect impact on productivity growth is negative because they play a negative effect in each sector where their impact is significant: agriculture, construction and low-services. Tunisian's ethnic group have a negative indirect and total effects in total productivity growth and in each sector excluded services. Following the reasoning for Morocco, the result proves that also Tunisian commute but, contrary to Moroccan, they depress productivity growth. Finally, Indians are significant only in the construction sector and for indirect and total effects. 


\begin{tabular}{|c|c|c|c|c|c|c|c|c|}
\hline & \multicolumn{4}{|c|}{ Total } & \multicolumn{4}{|c|}{ Agriculture } \\
\hline & Direct & Indirect & Total & & Direct & & Indirect & Total \\
\hline \multirow[t]{2}{*}{ GVA_EMP } & $-0.27398 * * *$ & -0.06019 & -0.33417 & $* * *$ & -0.40508 & $* * *$ & -0.01264 & $-0.41772 * * *$ \\
\hline & $(-11.45443)$ & $(-1.18512)$ & $(-5.6400)$ & & $(-15.49961)$ & & $(-0.18955)$ & $(-5.66926)$ \\
\hline \multirow[t]{2}{*}{ Albania } & 0.0003 & 1.14845 & 1.14876 & & -7.57637 & $* *$ & $17.85257 * *$ & 10.27620 \\
\hline & $(0.00057)$ & $(0.97394)$ & $(0.98705)$ & & $(-1.98326)$ & & (2.21819) & $(1.24714)$ \\
\hline \multirow[t]{2}{*}{ Romania } & $-0.55849 * *$ & $-1.60704 * * *$ & -2.16553 & $* * *$ & -1.14291 & & $-7.02323 *$ & $-8.16614 *$ \\
\hline & $(-2.27295)$ & $(-2.8521)$ & $(-3.93853)$ & & $(-0.69287)$ & & $(-1.68158)$ & $(-1.96370)$ \\
\hline \multirow[t]{2}{*}{ China } & $-1.2101 * * *$ & -1.13543 & -2.34553 & $*$ & 1.64762 & & $16.11972 *$ & 17.76734 \\
\hline & $(-2.91496)$ & $(-0.97351)$ & $(-1.68542)$ & & $(0.54911)$ & & $(1.82845)$ & $(1.65919)$ \\
\hline \multirow[t]{2}{*}{ Philippines } & $4.28619 *$ & 8.59179 & 12.87799 & $*$ & -8.68231 & & 74.59894 & 65.91664 \\
\hline & $(1.83605)$ & $(1.40247)$ & $(1.84061)$ & & $(-0.52554)$ & & $(1.65382)$ & (1.27487) \\
\hline \multirow[t]{2}{*}{ Morocco } & -0.72308 & $3.76741 * *$ & 3.04433 & & 2.91231 & & $21.88336 *$ & $24.79567 *$ \\
\hline & $(-0.81919)$ & $(2.1345)$ & $(1.60542)$ & & $(0.46772)$ & & $(1.70922)$ & $(1.79203)$ \\
\hline \multirow[t]{2}{*}{ Moldova } & $-2.36641 * * *$ & -1.18225 & -3.54867 & $*$ & -5.49694 & & $-24.39871 *$ & $-29.89565 * *$ \\
\hline & $(-3.44624)$ & $(-0.66307)$ & $(-1.73929)$ & & $(-1.1362)$ & & $(-1.86904)$ & $(-1.98467)$ \\
\hline \multirow[t]{2}{*}{ Poland } & $6.25324 * * *$ & 3.72163 & 9.97486 & $* *$ & 68.84227 & $* * *$ & -32.82213 & 36.02014 \\
\hline & (3.38643) & (1.06177) & $(2.45826)$ & & $(5.55743)$ & & $(-1.22509)$ & (1.19696) \\
\hline \multirow[t]{2}{*}{ Tunisia } & 0.69253 & $-10.80425 * * *$ & -10.11171 & $* *$ & -1.83511 & & $-50.00209 * *$ & $-51.83720 *$ \\
\hline & $(0.48401)$ & $(-3.27643)$ & $(-2.61587)$ & & $(-0.19115)$ & & $(-2.04202)$ & $(-1.85767)$ \\
\hline \multirow[t]{2}{*}{ Ukraine } & $-2.36882 * *$ & 3.14469 & 0.77588 & & -8.46684 & & -12.77348 & -21.24032 \\
\hline & $(-2.36478)$ & $(1.37523)$ & $(0.35149)$ & & $(-1.18866)$ & & $(-0.74702)$ & $(-1.28137)$ \\
\hline \multirow[t]{4}{*}{ India } & -1.13824 & 2.22821 & 1.08997 & & -4.57811 & & 8.59408 & 4.01597 \\
\hline & $(-1.60143)$ & $(1.29511)$ & $(0.61243)$ & & $(-0.92463)$ & & $(0.67888)$ & $(0.30378)$ \\
\hline & & Industry & & & & & Construction & \\
\hline & Direct & Indirect & Total & & Direct & & Indirect & Total \\
\hline \multirow[t]{2}{*}{ GVA_EMP } & $-0.26509 * * *$ & $-0.14473 * *$ & -0.40982 & $* * *$ & -0.39455 & $* * *$ & $-0.24275 * * *$ & $-0.63729 * * *$ \\
\hline & $(-10.72699)$ & $(-2.36043)$ & $(-5.90554)$ & & $(-13.72708)$ & & $(-3.01009)$ & $(-6.88268)$ \\
\hline \multirow[t]{2}{*}{ Albania } & $3.18965 *$ & -0.37751 & 2.81214 & & -1.11054 & & 6.54024 & 5.42969 \\
\hline & (1.95757) & $(-0.11247)$ & $(0.83782)$ & & $(-0.62482)$ & & (1.19624) & $(0.92946)$ \\
\hline Romania & -0.57029 & -1.77081 & -2.34109 & & 0.85977 & & 1.92047 & 2.78025 \\
\hline
\end{tabular}




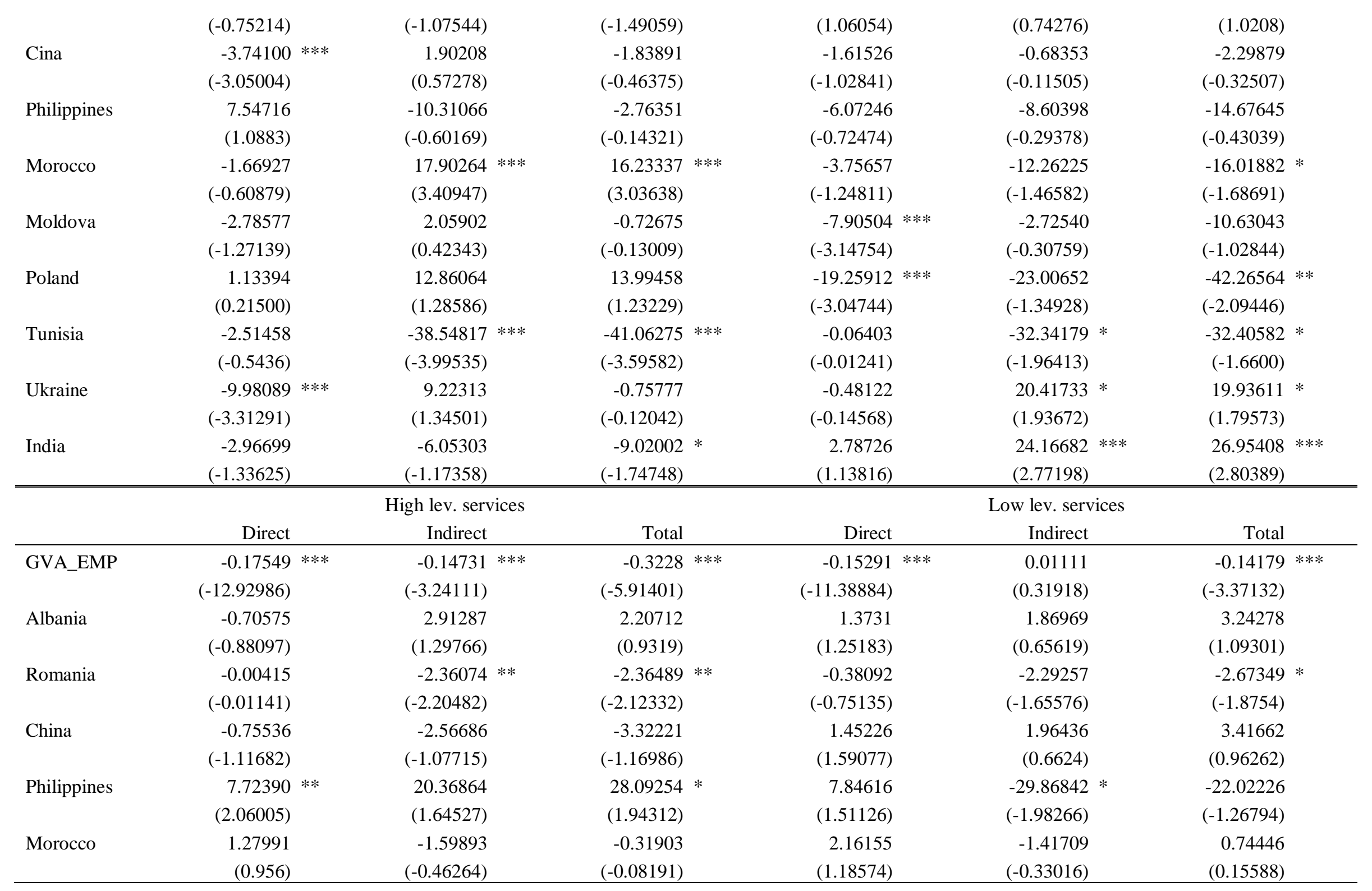




\begin{tabular}{|c|c|c|c|c|c|c|}
\hline Moldova & $\begin{array}{r}-1.30405 \\
(-1.21102)\end{array}$ & $\begin{array}{l}-1.90385 \\
(-0.5412)\end{array}$ & $\begin{array}{r}-3.20790 \\
(-0.78909)\end{array}$ & $\begin{array}{l}-3.51458 * * \\
(-2.41651)\end{array}$ & $\begin{array}{l}-7.71129 * \\
(-1.74603)\end{array}$ & $\begin{array}{l}-11.22587 * * \\
(-2.20186)\end{array}$ \\
\hline Poland & $\begin{array}{l}4.89637 * \\
(1.75018)\end{array}$ & $\begin{array}{r}-1.14961 \\
(-0.16697)\end{array}$ & $\begin{array}{r}3.74676 \\
(0.46086)\end{array}$ & $\begin{array}{l}4.69414 \\
(1.2346)\end{array}$ & $\begin{array}{r}1.51603 \\
(0.17691)\end{array}$ & $\begin{array}{r}6.21017 \\
(0.61625)\end{array}$ \\
\hline Tunisia & $\begin{array}{r}-2.11162 \\
(-0.93962)\end{array}$ & $\begin{array}{r}-0.94095 \\
(-0.14327)\end{array}$ & $\begin{array}{r}-3.05257 \\
(-0.39126)\end{array}$ & $\begin{array}{l}-2.23857 \\
(-0.7369)\end{array}$ & $\begin{array}{r}5.80631 \\
(0.71164)\end{array}$ & $\begin{array}{r}3.56773 \\
(0.36874)\end{array}$ \\
\hline Ukraine & $\begin{array}{r}1.57545 \\
(1.06718)\end{array}$ & $\begin{array}{r}0.60103 \\
(0.14013)\end{array}$ & $\begin{array}{r}2.17648 \\
(0.49242)\end{array}$ & $\begin{array}{r}-2.83587 \\
(-1.38223)\end{array}$ & $\begin{array}{r}2.50472 \\
(0.46066)\end{array}$ & $\begin{array}{r}-0.33114 \\
(-0.05992)\end{array}$ \\
\hline India & $\begin{array}{r}-1.49735 \\
(-1.40293) \\
\end{array}$ & $\begin{array}{r}5.76677 * \\
(1.70278) \\
\end{array}$ & $\begin{array}{r}4.26942 \\
(1.16094) \\
\end{array}$ & $\begin{array}{r}0.73500 \\
(0.50018) \\
\end{array}$ & $\begin{array}{l}5.83034 \\
(1.3509) \\
\end{array}$ & $\begin{array}{l}6.56534 \\
(1.4073) \\
\end{array}$ \\
\hline
\end{tabular}

*Significant at 1\%, ** significant at 5\%, *** significant at 10\%. t-stat in brackets.

Table 4: estimation of spatial effects 
Given the structural break in 2008, detected by the Chow model in table 3, we repeat the empirical analysis dividing the observed period in two sub-periods: 2003-2008 and 2008-2011. ${ }^{8}$ In spite of the short time periods considered, we explore the short term impacts of ethnic groups in table 5, where only the signs of the significant impacts are reported. The sign and significance of coefficients tend to change with respect to the coefficients estimated on the whole period. In particular, in the first sub-period only Moldova is always significant for whole productivity growth, with a negative effect. Ukrainians have a positive indirect and total impact and Polishes only direct positive one. In the second sub-period Indians are negatively correlated to growth for all the effects, and Romanians only for indirect and total impacts, while other foreign groups do not affect growth. Focusing on single sectors, in 2003-2008 time span the sign and significance of coefficients for people from Moldova are positive as in table 4, but Marroquin ethnic group becomes not significant and Albanian have positive direct and negative indirect effect that leads to insignificant total effect. Chinese ethnic group becomes positively significant in its indirect and total effect. During period 2008-2011 only Tunisian people have negative direct effects and Marroquins a positive one. In industry we have only an indirect negative and total effect for Tunisia during 2003-2008 period, and a negative direct and total impact for Romania and a positive indirect and total impact for India in the 2008-2011 period. As regard to the construction sector, we observe a higher number of significant foreign groups, with different behaviours in the two sub-periods. Moldavian and Polish's negative direct effects during 2003-2008 turn to be insignificant in the following period. Tunisian group plays a strongly negative indirect and total effect in the second sub-period. Ukrainians have a positive indirect and total impact in the first sub-period and Romanians a positive impact. In the case of high-services Filipino minority confirms the positive direct, indirect and total effect, but only in the first sub-period, while other foreign groups are not significant. In the second sub-period,

\footnotetext{
${ }^{8}$ The detailed tables of results are available upon request.
} 
with the exception of the positive indirect and total impact of Indians, no ethnic minorities are significantly different from zero. As regard to the low-services, we have that only Romanians have an indirect and total effect on growth in the first sub-periods. Finally, Indians, Albanian and Moldavians have a negative direct impact in the second sub-period, and Chinese people have a weak direct, indirect and total negative impact. 


\begin{tabular}{|c|c|c|c|c|c|c|c|c|c|c|c|c|c|c|c|c|c|c|}
\hline \multicolumn{19}{|c|}{ 2003-2008 } \\
\hline & \multicolumn{3}{|c|}{ Total } & \multicolumn{3}{|c|}{ Agriculture } & \multicolumn{3}{|c|}{ Industry } & \multicolumn{3}{|c|}{ Construction } & \multicolumn{3}{|c|}{ High lev. services } & \multicolumn{3}{|c|}{ Low lev. services } \\
\hline & Dir. & Indir. & Total & Dir. & Indir. & Total & Dir. & Indir. & Total & Dir. & Indir. & Total & Dir. & Indir. & Total & Dir. & Indir. & Total \\
\hline GVA_EMP & - & - & - & - & & - & - & & - & - & - & - & - & & - & - & & \\
\hline Albania & & & - & - & + & & & & & & & & - & & & & & \\
\hline Romania & & & & & & & & & & & + & + & & & & & - & - \\
\hline China & & & & & + & + & - & & & & & & & & & & & \\
\hline Philippines & & & & - & & & & & & - & & & + & + & + & + & & \\
\hline Morocco & & + & & & & & & & & & & & & & & & & \\
\hline Moldova & - & - & - & & - & - & & & & - & & - & - & & & - & & - \\
\hline Poland & + & & & + & & & & & & - & - & - & & - & & & & \\
\hline Tunisia & & & & & & & & - & - & & & & & & & & & \\
\hline Ukraine & & + & + & - & & & & & & & + & + & + & & + & & & \\
\hline \multicolumn{19}{|l|}{ India } \\
\hline \multicolumn{19}{|c|}{ 2008-2011 } \\
\hline & \multicolumn{3}{|c|}{ Total } & \multicolumn{3}{|c|}{ Agriculture } & \multicolumn{3}{|c|}{ Industry } & \multicolumn{3}{|c|}{ Construction } & \multicolumn{3}{|c|}{ High lev. services } & \multicolumn{3}{|c|}{ Low lev. services } \\
\hline & Dir. & Indir. & Total & Dir. & Indir. & Total & Dir. & Indir. & Total & Dir. & Indir. & Total & Dir. & Indir. & Total & Dir. & Indir. & Total \\
\hline GVA_EMP & - & - & - & - & & - & - & - & - & - & - & - & - & - & - & - & & - \\
\hline Albania & & & & & & & & & & & + & + & & & & - & & \\
\hline Romania & & - & - & & & & & - & - & & - & - & + & - & & - & & \\
\hline China & & & & & & & & & & & & & & & & - & - & - \\
\hline \multicolumn{19}{|l|}{ Philippines } \\
\hline Morocco & & & & + & & & & & & & & & & & & & & \\
\hline Moldova & & & & & & & & & & & & & & & & - & & \\
\hline \multicolumn{19}{|l|}{ Poland } \\
\hline Tunisia & - & & & - & & & - & & & & - & - & & & & - & & \\
\hline Ukraine & & & & & & & & & & & & & + & & & + & & \\
\hline India & - & - & - & & & & - & + & + & & & & & + & + & - & + & \\
\hline
\end{tabular}


To sum up, our findings show that the spatial distribution of foreign groups across provinces seems to be not efficient in terms of productivity growth. On average, the sectors suffering more for the spatial mismatch between local demand and foreign labour supply are agriculture and industry, followed by construction, while services sectors are only marginally affected. These results are in line with Bettin et al. (2014) who find that, in the Italian economic system, an increase in the adoption of foreign workers may change the manufacturing output mix in favour of low skill intensive sectors. This can be due to the problem that Italy mainly attracts unskilled immigrants, and the few high-skilled immigrants moving to this country are often employed in traditional sectors and fill low-skilled jobs, suffering from substantial overeducation (Bratti and Conti, 2014). The negative impact on (level) productivity, on the other hand, is in line with the findings of Kangasniemi et al. (2012) and Nicodemo (2013) for Spain, but in contrast with the positive effects on productivity growth of Rolfe et al. (2013) for United Kingdom. Finally, our outcomes are in line with González and Ortega (2011) that, analysing the Spanish case, find that the response of the industry to an increase in unskilled labor force is to use the more abundant type of labor more intensively. In this extent the raise of immigration contributes to change production technologies of industry toward a more labour intensive paradigm because the availability of cheap labor due to legislative changes in favour of more flexibility labour market introduced by the Prodi Government in 1997-98 caused a decline of the equilibrium capital-labour ratio (Daveri and Parisi, 2010).

\section{Conclusions}

In this paper we apply a spatial empirical framework to assess the impact of ethnic communities 
on Italian sectoral productivity growth. The number of foreign residents has increased steadily over time and their distribution has been concentrated in provinces where people of the same nationality have already settled down. This process stops with the crisis, when foreign groups start to deconcentrate.

The empirical analysis is based on a spatial panel Durbin model, which allows to assess the role and the strengths of ethnic communities on sectoral productivity growth. The most interesting point is the diffused negative impact of foreign groups on sectoral productivity growth, due not only to the direct impact, but also to the indirect effect, which is so strong that is able to negatively reverberate through the whole economy. This is not related to the evidence that immigrants are generally located in the more developed regions, which present higher income per capita levels: the correlation with the initial sectoral GVA per employee, in fact, is very weak. Furthermore, we do not find a common pattern across sectors: different ethnic groups have differentiated or null impact in function of the type of sector.

A possible explanation of these findings is that in some provinces there is a spatial mismatch between labour demand and supply such that foreign people increase the supply of labor and, in case of excessive supply, the per capita growth rate decreases. One could ask why foreign people decide to live in locations where the labor market is not able to exploit their skills. A first answer could be given by extending our analysis with a utility maximizing framework where immigrants are assumed as rational individuals who decide to live in those locations because destination-origin differences are such that the expected utility on the destination is still greater than the expected utility at the origin plus the cost of relocating. A second come form Haug (2008), that points out that, "as social networks are extended and strengthened by each additional migrant, potential migrants are able to benefit from the social networks and ethnic communities already established in the country of destination" pushing in the background other factors. Another interpretation of the results is that the lower wages devoted 
to foreigners imply that also skilled foreign workers do not find an adequate job, decreasing their productivity.

This problem can arise also from the migration rules requiring that extra-EU people have a job to live regularly in Italy, then they are willing to accept also a low level quality employment.

Our results give room to various policy interventions. The clearest evidence from this study is that clusterization is not a channel to improve sectoral productivity. This is probably also linked to the quality of migration and to the under-utilization of skilled labour force. This implies that policies aiming at avoiding spatial concentration and fostering integration and social inclusion could generate positive effects on productivity. The process has to go together with a more receptive labour market in which wages are proportional to skill and professional levels. This would also solve the self-selection problem (Bratti and Conti, 2014), making that immigrants coming to Italy fully utilise their skills. Immigrants, until now have been seen only as an increasing problem, but rarely as a missed development opportunity. In this extent it is probably time to do something that would benefit not only foreigners, but the whole society.

\section{References}

Alesina A., Devleeschauwer A., Easterly W., Kurlat S., and Wacziarg R. (2003), "Fractionalization", Journal of Economic Growth, 8: 155-194.

Anselin L. (2003) "Spatial externalities, spatial multipliers, and spatial econometrics", International Regional Science Review, 26: 153-166.

Barro R.J. (2000) "Inequality and growth in a panel of countries", Journal of Economic Growth, 3: 5-32.

Barro R.J. and McCleary R.M. (2003) "Religion and economic growth across countries", American Sociological Review, 68: 760-781.

Barro R.J. and Sala-i-Martin X. (2003) Economic growth, $2^{\text {nd }}$ Edn. MIT Press, Cambridge, MA.

Bettin G., Lo Turco A., and Maggioni D. (2014) “A firm level perspective on migration: the role of extra-EU workers in Italian manufacturing", Journal of Productivity Analysis, 


\section{2: $305-325$.}

Bratti M., and Conti C. (2014) "The effect of (mostly unskilled) immigration on the innovation of Italian regions", IZA DP No. 7922.

Easterly W. and Levine R. (1997) “Africa's growth tragedy: Policies and ethnic divisions”, Quarterly Journal of Economics, 12: 1203-1250.

Daveri F. and Parisi M.L. (2010), "Temporary Workers and Seasoned Managers as Causes of Low Productivity" Ifo/CESifo \& OECD Conference on Regulation: Political Economy, Measurement and Effects on Performance, Jan. 2010, Munich.

EC (2014) Sixth report on economic, social and territorial cohesion, European Commission, Bruxelles.

Elhorst, J. P. (2010) “Applied Spatial Econometrics: Raising the Bar”. Spatial Economic Analysis, 5: 9-28.

Elhorst J.P. (2014) Spatial Econometrics From Cross-Sectional Data to Spatial Panels, Springer: Berlin New York Dordrecht London.

Ertur C., Koch W. (2007) "Growth, technological interdependence and spatial externalities: theory and evidence", Journal of Applied Econometrics, 22: 1033-1062.

Fingleton B. and Lopez-Bazo E. (2006) “Empirical growth models with spatial effects”, Papers in Regional Science, 85(2), pp. 177-198.

Fratesi U. and Percoco M. (2014) "Selective migration, regional growth and convergence: Evidence from Italy", Regional Studies, 48: 1650-1668.

de la Fuente, A. and Doménech, R. (2006) "Human capital in growth regressions: how much difference does data quality make? An update and further results", Journal of the European Economic Association, 1(4), 1-36.

González L. and Ortega F (2011) "How do very open economies adjust to large immigration flows? Evidence from Spanish regions", Labour Economics, 18, 57-70.

Gören E. (2014) “How Ethnic Diversity Affects Economic Growth", World Development, 59, 275-297.

Haug S. (2008) "Migration Networks and Migration Decision-Making” Journal of Ethnic and Migration Studies, 34, 585-605.

IDOS (2010) Dossier statistico immigrazione, Caritas/Migrantes 2010, Rome, Italy.

INEA (2009) Gli immigrati nell'agricoltura italiana, Rome, Italy.

Kangasniemi M., Mas M., Robinson C., and Serrano L. (2012) "The economic impact of migration: Productivity analysis for Spain and the UK", Journal of Productivity Analysis, 38: 333-343. 
Kelejian H.H., Prucha I.R., Yuzefovich Y. (2006) "Estimation problems in models with spatial weighting matrices which have blocks of equal elements", Journal of Regional Science, 46: 507-551.

Leone Moressa Foundation (2012) Le professioni ricoperte dagli occupati stranieri - anno 2011, Mestre, Italy.

LeSage J.P., and Fischer M.M. (2008) "Spatial growth regressions: Model specification, estimation and interpretation", Spatial Economic Analysis, 3: 275-304.

LeSage J. P., and Pace R. K. (2009a) Introduction to spatial econometrics, Taylor \& Francis CRC Press, Boca Raton.

LeSage J. P., and Pace R. K. (2009b) "Spatial econometrics models", in: Fischer M.M., and Getis A (eds.) Handbook of applied spatial analysis. Springer, Berlin, Heidelberg and New York: 355-576.

Mankiw N.G. (1995) "The Growth of Nations". The Brooking Papers on Economic Activity, 1: 275-326

Ministero dell'Interno (2007) $1^{\circ}$ Rapporto sugli immigrati in Italia, Rome, Italy.

Ministero dell'Interno (2012), $2^{\circ}$ Secondo rapporto annuale sul mercato del lavoro degli immigrati - 2012, Rome, Italy.

Montalvo J. and Reynal-Querol M. (2005), "Ethnic diversity and economic development", Journal of Development Economics, 76: 293-323.

Nicodemo C. (2013) "Immigration and labor productivity: New empirical evidence for Spain", IZA DP No. 7297.

Noland M. (2005) "Religion and economic performance", World Development, 8: 1215-1232.

Quah D. (1996) "Regional Convergence Clusters across Europe". European Economic Reviews, 40: 1951-1958.

Ramos P., Suriñach J, and Artís M. (2010) "Human capital spillovers, productivity and regional convergence in Spain", Papers in Regional Science, 89, 435-448.

Rolfe H., Rienzo C., Lalani M., and Portes J. (2013) "Migration and productivity: employers' practices, public attitudes and statistical evidence", National Institute of Economic and Social Research, London.

Sala-i-Martin X., Doppelhofer G., and Miller, R.I. (2004) "Determinants of long-run growth: A Bayesian averaging of classical estimates (BACE) approach", American Economic Review, 94: 813-835. 